The Gender of Freedom 

Elizabeth Maddock Dillon

\section{The Gender of Freedom}

Fictions of Liberalism and the Literary

Public Sphere

Stanford University Press, Stanford, California 2004 
Stanford University Press

Stanford, California

(C) 2004 by the Board of Trustees of the

Leland Stanford Junior University

Printed in the United States of America

Library of Congress Cataloging-in-Publication Data

Dillon, Elizabeth Maddock

The gender of freedom : fictions of liberalism and the literary public sphere / Elizabeth Maddock Dillon

$$
\text { p. } \mathrm{cm} \text {. }
$$

Includes bibliographical references and index.

ISBN 0-8047-2941-7 (acid-free paper)

1. American literature-Colonial period, ca. 1600-1775-History and criticism. 2. Liberty in literature. 3. Dickinson, Emily, 1830-1886-Criticism and interpretation. 4. American literature-1783-1850-History and criticism. 5. Politics and literature-United States-History. 6. Women and literature-United States-History. 7. Sentimentalism in literature.

8. Liberalism in literature. 9. Sex role in literature. 10. Marriage in literature.

11. Women in literature. I. Title.

PS169.L5 D55 2004

$810.9^{\prime} 3552-\mathrm{dc} 21$

2003025733

This book is printed on acid-free, archival quality paper.

Original printing 2004

Last figure below indicates year of this printing:

$\begin{array}{llllllllll}13 & 12 & 11 & 10 & 09 & 08 & 07 & 06 & 05 & 04\end{array}$

Typeset in 10/13 Minion

The Hilles Publication Fund has provided support for the publication of this book. We gratefully acknowledge this assistance. 
FOR JOHN 
